保健物理, 18, 397 401（1983）

解説

\title{
$\mathrm{OECD} / \mathrm{NEA}$ による放射性廃棄物管理分野の活動
}

\author{
村 野徹*1
}

（1983 年 9 月 30 日受理）

Activities on Radioactive Waste Management by OECD/NEA

Tohru MURANO*1

KEY WORDS : international cooperation, radioactive waste management

\section{I 序}

放射性廃棄物の問題は，技術面から社会的側面までを 含む,きわめて広い領域と関連している。この問題につ いては，原子力利用を行っている各国が，それぞれ独自 の取組みをしているのと並行して, 国際的にも活発な活 動が行われている。そのよらな活動を行っているおるな 国際組織は, IAEA および OECD である。

本稿では, OECD が行っている放射性廃棄物管理に関 する活動をとりあげ，その概要を述べるとともに，その ような活動を通してみられるこの分野の動向にも若干触 れてみたいと思う。

OECDは, 周知のとおり, 日本語訳で経済協力開発機 構といわれている。IAEA が国連を基礎とした文字どお りほとんど全世界の国が加盟している国際組織なのに対 し, OECD は, 西側の “開発国” の国際組織である。 OECD の原子力分野の活動を行う部門として, NEA (Nuclear Energy Agency) が設置されている。

一般に, 国際機関の活動は, 加盟国の要請にもとづい て行われるのが通常である。NEA の廃棄物分野の活動 も，NEA 加盟国の要請が基礎となっている。このよう な意味から, 廃棄物問題が NEA に拈いてどのよらに取

*1 動力炉 - 核燃料開発事業団東海事業所技術部; 茨城県那 珂郡東海村村松 4-33 (个319-11)

Fuel Cycle Technology Development Division, Tokai Works, Power Reactor and Nuclear Fuel Development Corporation; Muramatsu 4-33, Tokai-mura, Naka-gun, Ibaraki-ken.
り上げられているかをみることは，NEA 加盟国，すな わち，世界の主要な開発国が何を課題にしているかを知 る手がかりとなると同時に, 放射性廃棄物問題を理解す る上で，参考になりらるものと思われる。

本稿を記述するための資料として，主として NEA の 年報1を使用した。

\section{II 経 過}

$\mathrm{OECD} / \mathrm{NEA}$ は，すでに 25 年の活動の歷史がある。 しかし，廃棄物に関する活動が活発になったのは，1975 年以降である。この時期は，いわゆるエネルギー危機と の関連で, 原子力の平和利用がとくに注目され，それと ともに放射性廃棄物問題の解決の必要性が, 世界的に広 く認識されたときでもある。この時点において，国際エ ネルギー機関 (IEA) は, 廃棄物問題に関する国際協力 の推進についての提言を行った。各国が当時, 個別的に 行っていた廃棄物に関する研究を, 国際的なフレームワ 一クの中で調整し, 加速する必要があるという考觉のも そに, OECD がそのための指導機関 (Leading Organization）としての役割を果たすのはどうかというのが IEA の提言であった。

NEA は, 1975 年にこの提言をらけ入れ, 廃棄物分野 の活動を強化した。以上が大筋の経緯である。

NEA の活動は, (1)安全性 (Nuclear Safety), (2)放射 線防護 (Radiation Protection \& Public Health), (3) 廃棄物管理 (Radioactive Waste Management), (4)開 発 (Development), (5)科学 (Science), (6)法律 (Legal 
Affairs）の6 部門に分けて行われている。廃棄物は, 主 として(3に入るわけであるが，最近は，放射線防護拈よ び法律にも関連する幅広い問題として, 多角的な取扱い が行われるようになった。

\section{III 活動の目 標}

すでに述べたように，NEA の廃棄物分野にお活る活 動は 1975 年になって活発に行われるようになった。しか し，NEA の活動は，1980 年ごろを境いに変化してきて

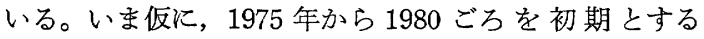
と, NEA の活動は現在, 次の段階に入っているとい光 る。初期に扮いて廃棄物問題は, 主として専門家の問題 として把兄られ，国際協力も各国の専門家グループの中 での討議, 情報交換, および共同研究であったとい光 る。しかし，1980 年ごろになると，この問題は，専門家 グループを超えたもっと広い枠組の中で把える必要があ るといら反省がなされた。このような考え方に従って, NEA は活動の重点をしだいに移行しつつあるとい党 る。

NEA が廃棄物分野の活動を行う際の基本的な考方方 を表すものとして，1981 年に NEA が定めた活動の目 標を第 1 表に示す。第 1 表は, NEA の年報（1981）に ある文章を訳したものである。ここには，NEA のプロ グラムが，最終的には，一般公衆の廃棄物問題に対する 理解の向上にもっと役に立つょうに努力したいといら意 四が表わされているとみることができる。

\section{NEA の活動の概要}

放射性廃棄物管理の分野について，NEA がとりあげ てきた項目を第 2 表に示す。これらの項目の一部につ き，その内容を簡単に紹介する。

\section{1. 基本問題または一般的研究}

（1）この部類に入る研究の成果で最も有名なものは, いわゆる “Polvani 報告”2)（1977）である。正式な名称 は，“原子力発電プログラムから発生する放射性廃棄物 管理飞関する，目標 (objectives)，概念 (concepts)，お よび戦略 (strategies)”である。これは NEA が組織し た專門家グループによる，廃棄物問題についての包括的 研究成果をまとめた報告書である。ここには，放射性廃 棄物管理の技術面抢よび技術以外の側面について，当面 する課題, 対策, 拉よび今後の活動についての勧告が述 ベられている。この報告書は，国際的に広く活用され， かつ高い評価をうけてきた。われわれの当面している廃 棄物問題の全貌を知る上で，この報告書はいまなお有用 である。
第 1 表 放射性廃棄物管理の分野に打ける NEA ブ ログラムの目標

目標-1 各国の放射性廃棄物管理和よび実証(Demonstration*) 計画を支援するため，研究を 推進し，そのためのデータベースを充実す る。

目標-2 各国の放射性廃棄物管理プログラムと，施 策を支援するため, 研究開発の成果を有効 に活用する。

目標-3 放射性廃棄物管理に関するさまざまな問題 点およびさまざまな方法一とくに処分の分 野一について理解を向上させる面で加盟国 を支援する。

* 放射性廃棄物のきわめて長期にわたる隔離技術に ついて，実証（Demonstration）という用語がよ く使われているが，その定義あるいは内容につい てどう理解したらよいか，専門家による検討が行 われ，その報告が NEA から出される予定であ る。

第 2 表 放射性廃棄物管理の分野に拈ける NEA の 活動項目

I 基本問題または一般的研究

(i) 長期的放射線防護の目標の確立*

(ii）廃棄物処分のフィロソフィー**

(iii） 廃棄物の長期管理**

II 技術面の研究開発等

(i) 気体廃棄物の管理

（ii）アルファ廃棄物の処理

(iii） ウラン鉱滓の管理

(iv) 長寿命廃棄物の核変換

（v）低レベル廃棄物の海洋処分

（vi） 原子力施設の解体

（vii）地層処分

(viii) 海洋底処分

* 放射線防護と廃棄物管理の両方にまたがる課題で ある。

** 法律と廃棄物管理の両方にまたがる課題である。

（2） NEA は，放射性廃棄物の処分についてのフィロ ソフィィーについて検討を行い，その成果を 1982 年に小 冊子にまとめ出版し，無償で配布した。小冊子の名称 は, “放射性廃棄物の処分3””で副題として，一そこに含 まれる諸原則の検討一がつけられている。ここでは，処 分の根底にある基本的考え方，たとえば，将来の世代に 対する責任，あるいは，処分行為がどのような論理に基 
づいて容認されるかというような問題について，平易な 言葉で解説されている。これは，処分に関する技術面の 研究を補足するものである。

（3）廃棄物管理の放射線安全面の重要な課題として, “長期的な放射線防護目標の確立” (Development of Long-Term Radiation Protection Objectives) がとり あげられている。この課題は次のよらに説明されてい る。すなわち, ある種の放射性廃棄物は, きわめて長期 にわたって放射性である。この場合, 非常に遠い将来に ついて処分の安全性の評価を行おうとすると, どうして も不確実性 (Uncertainties) が入ってくる。そこで, ICRP 勧告に基づき, かつ, 廃棄物の処分に直接適用で きる, 放射線防護の目標 (Objectives) が確立されなけ ればならない。また，そのような目標につき，世界的に 共通した理解がなされる必要があるといらことである。 このために（亿公衆に対する放射線被曝の上限について の目標をどらするか，(口)処分に由来すると予測されるマ イナス面を，合理的な範囲で低くおさえるのには，ぞう いら方法をとるべきかの 2 点につき検討作業が現在行わ れている。

\section{2. 技術面の研究開発等}

（1）低レベル廃棄物の海洋処分 ${ }^{4)}$

低レベル放射性廃棄物の海洋処分は，いわゆるロンド ン条約により規制されている。OECD はこれに対し, 国際的監視機構 (OECD Multilateral Consultation and Surveilance Mechanism for Sea Dumping of Radioactive Waste) を 1977 年に設置した。各国は, 海洋処 分を規制に従って実施していることを明らかにするた め, OECD の機構を活用しているわけである。この機構 には, 1981 年現在, 日本を含めて 21 カ国が入っている。

NEA は, 上述の活動と並行して, 現在使用している 海洋処分サイトを引き続さ使用するのが適切かどうかを 評価するため, 科学的な調査研究を実施している。

低レベル廃棄物の海洋処分は, 世界各国の合意があっ てはじめて実施できる。この合意をらるための努力が， NEA を通して精力的に続けられている。

(2) 除染および解体 ${ }^{5}$,6)

原子力施設の除染および解体 (decommissioning) は, 将来, 相当量の放射性廃棄物の発生につながると考えら れることから，第一義的には廃棄物管理の課題とされて いる。NEA のこの課題についてのプログラムとして,

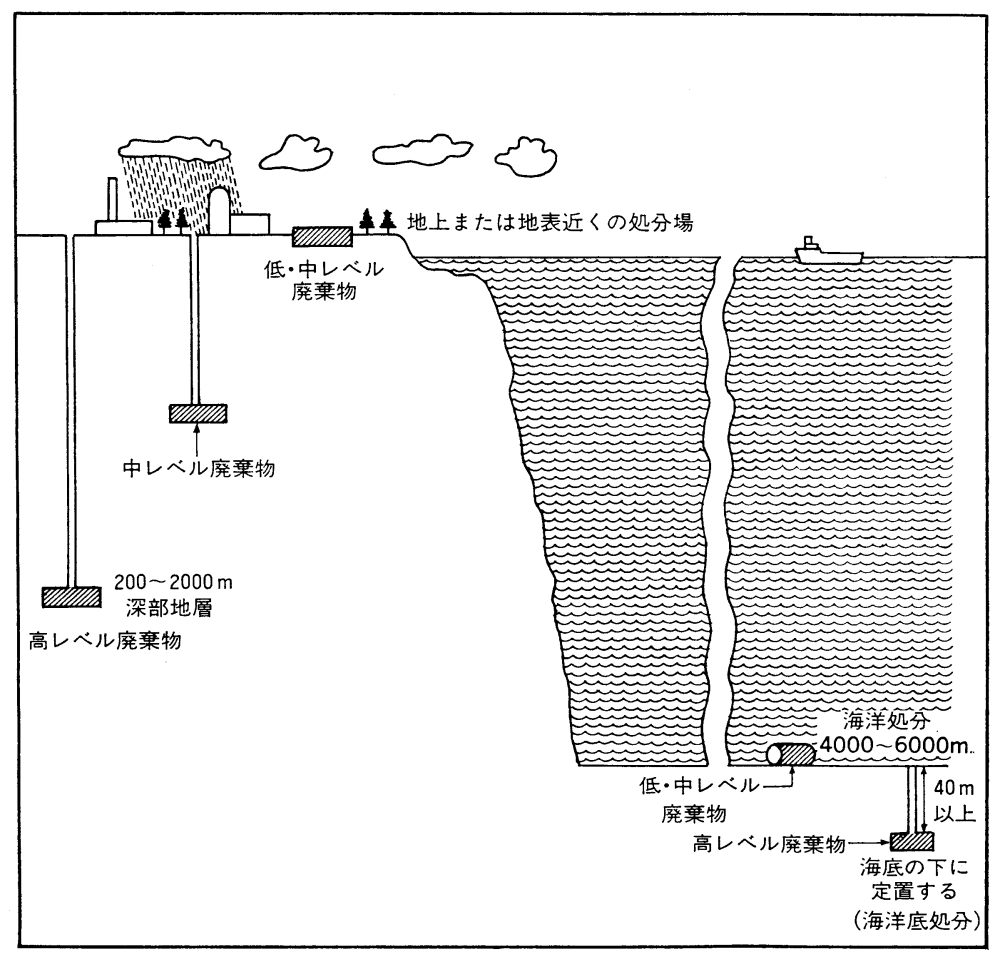

第 1 図 廃棄物処分のいろいろな方法の例（NEA 年報1980年より） 
現在, Ågesta 計画が進行中である。第 1 フェーズでは, さまざまな除染方法の実験室試験が行われ, 第 2 フェー ズでは，スウェーデンの Ågesta 原子炬を利用した実規 模試験が計画されている。1982 年に第 1 フェーズは終了 し，これから第 2 フェーズが開始されるところである。

（3）地層処分

地層処分 (Geologic Disposal)は, 1975 年以来, NEA の活動として重視されてきた課題の一つである。高レベ ル廃棄物拈よび TRU 廃棄物の上らに, 非常に長期間の 隔離が必要な廃棄物について, 実現の見込みの大きい処 分方法として，各国が地層処分に注目し，それを国際協 力に適した課題と考えた。地層処分に関しては，情報交 換执よび共同研究の両方について活発な活動が行われて いる。

（i） 情報交換

情報交換の方法としては, 主としてワークショップが 用いられている。地層処分の研究開発に直接結びっくテ ーマが選ばれ，すでに多くのワークショップが開かれ， その成果が公表されている。最近のものを例示すると， 1982 年には, 地層処分に関連する地球化学 プロセス (Geochemical Processes) についてのワークショップ7) が開かれている。ここでは, ガラス固化体が地下深部の 地球化学的条件下で浸出され, 地下水によって処分サイ トから移行する化学的メカニズムについて, 現在の知識 の水準からぞういらことがいえるかについて検討が行わ れた。るら一つのワークショップは, 地層処分に関連 し, サイトの特性を明らかにするための地球物理的手法 を対象として行われた ${ }^{8)}$ 。こでは, 結晶質岩および堆 積岩の岩体深部に存在する割れ目や地下水の流れを, remote sensing でぞのように検出するかが拈もな課題
であった。

地層処分についての技術的研究課題は，広くかつ新し い領域に及んでいる。NEA のワークショップは，各国 の研究者のよい情報交換の場となってきたといえる。

(ii）共同研究

NEA が現在実施している共同研究プロジェクトとし て, ストリパ計画と ISIRS 計画がある。前者は, 共同 実験計画であり, 後者は, 地層処分に必要なデータバン クを作る計画である。ISIRS とは, “Internationl Sorption Information Retrieval System” の略称である。 地圏（Geosphere）を放射性核種が地下水により移行す る現象を取り扱う場合，核種の岩石，鉱物等に対する吸 着 (Sorption) についての情報が不可欠である。ISIRS は，吸着に関する国際的データバンクを作り，広く活用 をはからうとするもので，プロジェクトの期間は，1981 ８4 年である。

以下, ストリパ計画について, 若干の解説的な説明を 加光ておく。地層処分の研究の歷史は 1950 年代まで溯 るが, 初期の研究の対象となった地層は, ほとんぞ岩塩に 限られた。1970年代に入ると，もっと普遍的に存在する岩 種が研究の対象とされるようになった。その一つが, 結晶 質岩の代表としての花崗岩である。地層処分は，地層深 部を利用する技術であるので, 研究開発の重要なステッ プとして, 原位置試験 (In-Situ Experiments) が不可欠 である。原位置試験とは, 対象とする岩種について, 実 際の岩体の深部試験場を設置し, 岩盤の力学的特性, 水理的特性等各種の試験を行うことを言う。スウェーデ ンのストリパでは，花崗岩について，地層処分に関する 最初の原位置試験が、スウェーデンーアメリカの 2 国間の 協力で，1977 80 年に実施された。スウェーデンは，こ

第 3 表 ストリパ計画の概要

\begin{tabular}{|c|c|c|c|c|c|}
\hline & フ & $=-$ & ズ & 第 1 フェーズ & 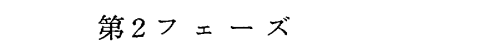 \\
\hline 期 & & 間 & & $1980 \sim 1984$ & $1983 \sim 1986$ \\
\hline 参 & 加 & 国 & & $\begin{array}{l}\text { アメリカ, スウェーデン, スイス, フ } \\
\text { ィンランド, 日本, フランス, カナダ } \\
\text { (7カ国) }\end{array}$ & $\begin{array}{l}\text { アメリカ, スウェーデン, スイス, フ } \\
\text { インランド, 日本, フランス, カナダ, } \\
\text { イギリス (8 カ国) }\end{array}$ \\
\hline
\end{tabular}

試験内容

工学バリア実規模試験

岩盤の調査技術開発

○バッファマス試験

○ボーリング孔による水理地質調查
。密封試験

。割れ目調査技術

(Crosshole Geophysics)

。割れ目内の水の移動と核種移行試験

。 3 次元トレーサ一試験 


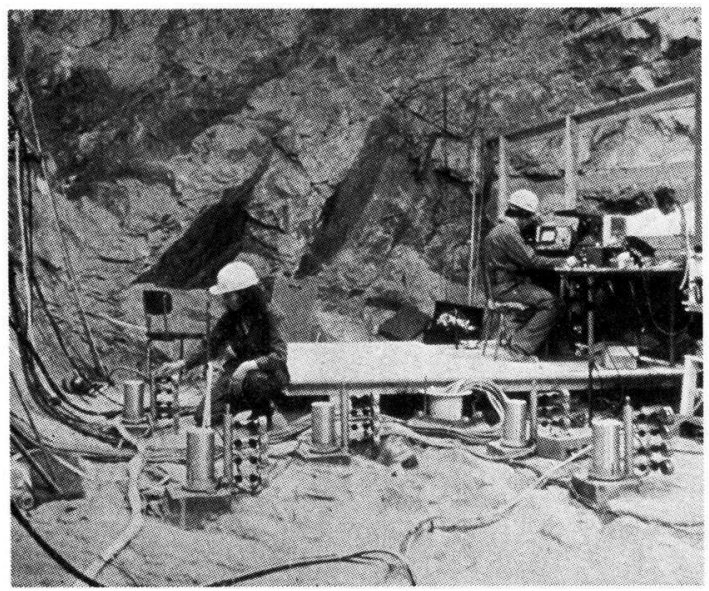

第2図 ストリパ（スウェーデン）に拈るる高レペ ル放射性廃棄物の地層処分の研究

の後, ストリパサイトを国際的共同試験場として使用す ることを NEA に提案した。これをもとに, NEA の国 際ストリパ計画 (International Stripa Project) が, 1980 年に発足した。花崗岩体の割れ目中の水の挙動を取 り扱う “Fracture Hydrology”割れ目中の物質移行 (Migration), 工学バリア (Engineered Barrier), 地球 物理的調査技術 (Borehole Geophysics) が研究課題と してとりあげられている。プロジェクトは, 第 1 , 第 2 フェーズにわけて進行しており, その概要を第 3 表に示 す。ストリパにおける原位置試験の最近までの成果は,

“放射性廃棄物の地層処分に関連する, 花崗岩中の原位 置試験についてのワークショップ”9) で発表された。

\section{(4) 海洋底処分}

高レベル放射性廃棄物の処分の一つのオプションとし て, 深海の堆積物中に廃棄物を定置する方法が提案され ており, 海洋底処分 (Seabed Disposal) と呼ばれてい る。NEA では, 地層処分の代替法の一つとして, この 方法についても, 作業グループを設置して, 検討を行っ ている。

\section{V む す び}

以上, OECD/NEA による放射性廃棄物管理の分野に おける活動の概要を述べた。これらの活動を通してみた 場合, NEA の活動の重点は, 長寿命の放射性廃棄物の
管理にあるといえる。放射性廃棄物問題の解決のために は, 広範囲にわたる専門分野の研究を結合する必要があ り,かつ, その成果が広く理解されなければならない。

NEA による活動は，このような要請に沿って効果的 に進められているといえる。

NEA の活動の成果は公表されており，それぞれの立 場で参考になるものと思われる。ちなみに, NEA の出 版物は, 東京, 赤坂の OECD 広報センターで容易に入 手できることを付言して报く。

\section{参考文 献}

1) NEA Activities in 1982, Eleventh Activity Repot of the OECD Nuclear Energy Agency (1982). (同種の報告が，年度ごとに発行されてい る。これを内容から判断し，本文では年報と呼ん だ。)

2) Objectives, Concepts and Strategies for the Management of Radioactive Waste Arising from Nuclear Power Programmes, Report by an NEA Group of Experts (1977).

3) Disposal of Radioactive Waste-An Overview of the Principles Involved-, OECD/NEA (1982).

4) Research and Environmental Surveillance Programme Related to Sea Disposal of Radioactive Waste (1981).

5) Decomissioning Requirements in the Design of Nuclear Facilities (1980).

6) Decontamination Methods as Related to Decommissioning of Nuclear Facilities (1981).

7) Geological Disposal of Radioactive WasteGeochemical Processes- (1982).

8) Geophysical Investigations in Connection with Geological Disposal of Radioactive Waste (1982).

9) In-Situ Experiments in Granite Associated with Geological Disposal of Radioactive Waste (1982). 